\title{
The Joint Estimation of Child Participation in Schooling and Employment: Comparative Evidence from Three Continents*
}

\author{
Pushkar Maitra \\ Department of Economics \\ Monash University \\ Clayton Campus \\ Victoria 3168 \\ Australia \\ Pushkar.Maitra@BusEco.monash.edu.au
}

\author{
Ranjan Ray \\ School of Economics \\ University of Tasmania \\ GPO Box 252-85 \\ Hobart, Tasmania 7001 \\ Australia \\ Ranjan.Ray@utas.edu.au
}

November 2000

\begin{abstract}
*We would like to thank participants at the North East Universities Development Conference 2000 held at Cornell University for their comments and suggestions. Ranjan Ray acknowledges financial support from the Australian Research Council, and the research assistance of Adrian Breen and Geoffrey Lancaster. Pushkar Maitra acknowledges financial support from the Faculty Research Grant Scheme, Faculty of Business and Economics, Monash University.
\end{abstract}




\begin{abstract}
This paper uses data from Peru, Pakistan and Ghana to simultaneously analyse child labour and child schooling, and compares them between these countries. We use a multinomial logit estimation procedure that analyses the participation and non participation of children in schooling and in employment and, in particular, allows the possibility that a child combines schooling with employment or does neither. We also use an ordered probit estimation procedure based on a ranking of the various child schooling/employment/non schooling/non employment outcomes. The results point to both similarities and striking dissimilarities in the nature of child labour and child schooling between the chosen countries. For example, in Pakistan, but not in Peru, the girl child's ordering of schooling/employment outcomes shows her at a position of extreme disadvantage. Household poverty discourages a child from achieving superior outcomes, but the effect varies markedly across the three countries.
\end{abstract}

JEL Classification: C2, D1, I3, J2, O1

Keywords: Child Labour, Child Schooling, Multinomial Logit, Ordered Probit 


\section{Introduction}

The prominence accorded to the subject of child labour at the recent WTO meeting in Seattle is a reflection of its pivotal importance for the setting of international labour standards in an era of rapid globalisation. There have been calls to set up a multi-country organisation that might help design policies to reduce the incidence of child labour. ${ }^{1}$ Though the ILO (1996)'s estimates on labour force participation rates for children aged 10-14 years show a declining trend, in absolute terms the size of the child labour force is and will continue to be large enough to be of serious concern. There is no universal agreement on the magnitude of the child labour force, reflecting differences in the definition of child labour and in their measurement. According to the ILO (1996), 120 million children world wide between the ages of 5-14 years have been engaged in full time paid work. If one includes part-time work as well, then the ILO (1996) estimate goes up to 250 million working children. The estimate of child labour would vary depending on how we define work, how we define a child, and how we collect the data, but few would disagree that this is a problem of gigantic proportions.

Notwithstanding almost universal agreement that child labour is undesirable, there is wide disagreement on how to tackle this problem. The formulation of policies that are effective in curbing child labour requires an analysis of its key determinants, namely, identification of variables that have a significant effect on child employment. For example, Bonnet (1993) argues in the African context that poor quality of child schooling and their lack of apparent relevance to the child's employment skills encourage parents to take their children out of schools and put them into employment. The evidence presented in Ray (2000a) shows that the nature of child labour, its key determinants and, consequently, the strategies aimed at reducing it, vary between countries. Child labour takes different form in different regions. Cross country comparisons, especially involving vastly different cultures and continents, enable better understanding of differences in the policies required to maximise their effectiveness in specific regional contexts. This paper extends Ray (2000a, 2000b) and jointly 
estimates school attendance and child labour market participation in Pakistan, Peru and Ghana. These countries span a wide and diverse geographical area and are sufficiently heterogeneous to make this comparative study of considerable interest.

The primary aim of this paper is to jointly estimate school attendance and child labour market participation and examine cross-country differences in these categories. A large part of the literature has used single equation based models to estimate the probability of school attendance and child labour market participation (see for example Patrinos and Psacharopoulos (1997), Psacharopoulos (1997), Jensen and Nielsen (1997) and Ray (2000a)). However these studies have two significant limitations. First, they overlook the fact that the decisions on school attendance and child labour market participation are not independent. Second, they do not take into account all the possibilities - in particular, the possibility that some children attend school and work in the labour market while some children do neither. ${ }^{2}$ In fact there are four possible alternatives to choose from: (a) child attends school only (and does not work), (b) child attends school but also works, (c) child works and does not attend school and (d) child does neither.

This paper adds to a limited but expanding literature on the joint estimation of child schooling and child employment equations that recognises their interdependence and simultaneity. There are alternative ways of jointly estimating a child's school attendance and her labour market participation. The first is the bivariate probit model used by Canagarajah and Coulombe (1997) and Nielsen (1999). This approach, while recognising the interdependence of child schooling and child labour decisions, does not consider all the possibilities. The second approach, (see Cartwright (1999), Grootaert (1999) among others ${ }^{3}$ ) uses a sequential probit model where the schooling/labour choices occur in multiple stages. In the first stage, the choice is between the most preferred option (which is attending school full time) and all other options. The second stage models the choice between the second best option and the remaining options, conditional on not having opted for the first best. The 
process continues until all choices are exhausted. The third approach, which is adopted in the present study (see also Cigno, Rosati and Tzannatos (2000) and Rosati and Tzannatos (2000)) is the simultaneous choice model based on the multinomial logit and the ordered probit models where the choice between the various alternatives is made at one particular point in time rather than sequentially. While the sequential approach to modelling the supply of child labour is interesting in its own right, we see no a priori reason to choose the sequential model over the simultaneous choice model. The latter, that is preferred in this study, entails estimation of one equation, which we think is more easily understood. ${ }^{4}$

The rest of this paper is organised as follows. Section 2 discusses the estimation procedures. Section 3 describes the data sets, and presents some selected descriptive statistics. Section 4 presents and discusses the estimation results. Concluding comments are presented in Section 5.

\section{Estimation Methodology}

The decision to send a child to work is described by the following latent variable model.

$$
W_{i}^{*}=X_{1 i} \beta_{1}+\varepsilon_{1 i}
$$

$W_{i}^{*}$ is the net benefit attained by the family by sending child $i$ to work, $X_{1 i}$ is a vector of child, family and community characteristics that determine $W_{i}^{*}$, and $\varepsilon_{1 i}$ is a random error, with zero mean and unit variance. However, $W_{i}^{*}$ is not observed - what we do observe is the following binary variable:

$$
W_{i}=\left\{\begin{array}{l}
1, \text { if the child works }\left(\mathrm{W}_{\mathrm{i}}^{*}>0\right) \\
0, \text { otherwise }
\end{array}\right.
$$

Correspondingly, the decision to send a child to school is described by the following latent variable model:

$$
S_{i}^{*}=X_{2 i} \beta_{2}+\varepsilon_{2 i}
$$


$S_{i}^{*}$ is the net benefit to the family from sending the child to school, $X_{2 i}$ is the vector of child, family and community characteristics that determine $S_{i}^{*}$, and $\varepsilon_{2 i}$ is a random error with zero mean, unit variance. $S_{i}^{*}$ is not observed - what we do observe is the following binary variable:

$$
S_{i}=\left\{\begin{array}{l}
1, \text { if the child works }\left(\mathrm{S}_{\mathrm{i}}^{*}>0\right) \\
0, \text { otherwise }
\end{array}\right.
$$

In the multinomial logit estimation procedure we convert the two-equation system (given by equations 1 and 2) into an observable form $(Y)$ involving four states as follows:

(i) $\quad Y_{i}=0: W_{i}^{*} \leq 0, \mathrm{~S}_{\mathrm{i}}^{*}>0$ (child does not work, attends school),

(ii) $\quad Y_{i}=1: W_{i}^{*}>0, \mathrm{~S}_{\mathrm{i}}^{*}>0$ (child works and attends school),

(iii) $\quad Y_{i}=2: W_{i}^{*} \leq 0, \mathrm{~S}_{\mathrm{i}}^{*} \leq 0$ (child neither works nor attends school) and

(iv) $\quad Y_{i}=3: W_{i}^{*}>0, \mathrm{~S}_{\mathrm{i}}^{*} \leq 0$ (child works, does not attend school).

The estimated equation is given by:

$$
Y_{i}=X_{i} \beta+\varepsilon_{i}
$$

The reduced form parameters of this equation are estimated using maximum likelihood based on a multinomial logistic distribution of $\varepsilon$. Since the probabilities of being in the 4 states (i) (iv) must add to unity for each child, the multinomial logit strategy involves estimating three equations. In this study, we have normalised category (ii), i.e. adopted the state of child working and attending school as the baseline case in the multinomial logit regressions.

The 4 choices mentioned above can be easily ranked in a descending order from the viewpoint of child welfare. The welfare based ordering is as follows: only school $(y=0)$, both school and work $(y=1)$, neither school nor work $(y=2)$, only work $(y=3)$. Equation (3) is re estimated as an ordered probit model that respects this welfare ordering. We assume that $\varepsilon$ is normally distributed across observations. The coefficients, $\beta$, have an unambiguous 
interpretation only with respect to the two extreme states $(y=0,3)$, not with respect to the middle ones $(y=1,2)$. The ordered probit model used here contrasts with the sequential probit model used by Grootaert and Patrinos (1999) recognising the ordering of the four alternatives. While the sequential probit model is interesting we stick to the ordered probit model because we think that the choices are made simultaneously rather than sequentially.

\section{Data and Descriptive Statistics}

The child labour data for the study came from the Peru Living Standards Measurement Survey (PLSS) in 1994, the Pakistan Integrated Household Survey (PIHS) in 1991, and the Ghana Living Standards Measurement Survey (GLSS) in 1988/89. These surveys were conducted jointly by the respective governments and the World Bank as part of the Living Standards Measurement Study (LSMS) household surveys in a number of developing countries $^{5}$. The purpose of the LSMS surveys is to provide policy makers and researchers with individual, household and community level data needed to analyse the impact of policy initiatives on living standards of households. The Pakistan Integrated Household Survey covered 4800 households, the Peru Living Standards Survey involved 3623 households, and the Ghana Living Standards Survey involved 3192 households. While the Peruvian sample contained information on child labour and child schooling of 5231 children aged $6-17$ years, the Pakistani data set yielded 5866 observations on children aged $10-17$ years, and the Ghanaian sample on 5245 children aged $7-17$ years. Some of these observations could not be used, however, because of poor quality. In this study, we follow the ILO definition of child labour (see Ashagrie (1993)) in classifying a child as a 'labourer' if the child does full time, paid work. While this limits our analysis to only a subset of child work, it makes our study comparable with others in the literature. ${ }^{6}$ 
Table 1 contains description of the variables used in this study. Tables $2 \mathrm{~A}-2 \mathrm{D}$ present comparative figures, for the 3 countries, of the percentage of children belonging to the 4 mutually exclusive and exhaustive employment/schooling states considered in this study. The figures, which also provide information on the gender differential, show some interesting dissimilarities and similarities between the three countries. First, a sizeable proportion of Pakistani and Ghanaian children are neither in employment nor in school. In contrast, the corresponding proportion of Peruvian children who belong to this category is considerably smaller. The large numbers of Pakistani children in this category is typical of the entire South Asian region [see Weiner (1996)]. Ravallion and Wodon (2000) recently observed that a targeted enrolment subsidy in rural Bangladesh increased schooling by far more than it reduced child labour. This is possibly explained by the fact that a large number of children, who were previously neither in employment nor in schooling, enrolled as a result of this subsidy. It is, perhaps, not unreasonable to expect a large number of these children to be involved in domestic duties. On this interpretation, the gender differential in favour of higher proportion of girls, vis-a-vis boys, involved in domestic duties exists in all countries. However, the size and statistical significance of such gender imbalance is nowhere as large or as pronounced as that in Pakistan. The actual gender differential will be still greater in Pakistan than these figures suggest since a girl that goes neither to work nor to school is much more likely to be helping out with household chores than her brother in the same category. Second, the gender imbalance in Pakistan in domestic duties reverses itself for older children (15 - 17 years) in the direction of greater participation by boys as we move to the category of full time, "economically active" children - more boys work than girls. The Pakistani experience is not, however, shared by Peruvian or Ghanaian children. Third, as noted in Patrinos and Psacharopoulos (1997), Ray (2000a), a much higher proportion of Peruvian children combine employment with schooling than in other countries. There exists a pronounced and large gender differential in favour of Pakistani and Peruvian boys in this 
category. It is, also, worth noting that in Ghana, though not in Pakistan, the proportion of children, especially boys, who combine employment with schooling rises quite sharply in the later age categories. Fourth, in case of pure school going children with no work involvement, while the enrolment rate in Peru starts to decline markedly only beyond 13 years, in case of Pakistan and Ghana the enrolment rate peaks around 11 and 9 years, respectively, and falls to alarmingly low levels, especially for older girls. Finally, the schooling participation rates of Peruvian children in all age groups are considerably higher than their Pakistani and Ghanaian counterparts. Moreover, the gender bias in favour of boys schooling in Pakistan contrasts sharply with a more even gender balance in case of Ghana and a reversal in favour of girls' schooling in case of Peru.

Further evidence on the difference between the nature of child labour in the three countries is contained in Table 3, which presents the share of household income contributed by child labour earnings. ${ }^{7}$ The following features are worth noting. First, the Peruvian household is much less dependent on child labour earnings than its counterpart in Pakistan or Ghana. Second, as we move from children who only work to those who combine schooling with employment, the share of child labour earnings in household income drops in all cases. Note, however, that the drop is the least in case of Peruvian girls suggesting that schooling has relatively little impact on their ability to contribute to the household income through their labour earnings. Third, the sizeable proportion of household income that comes from child labour, especially in Pakistan and Ghana, points to the high vulnerability of several households to poverty, if their access to child labour earnings is reduced or removed through legislation without corresponding improvement in credit availability or the employment opportunity of their adults. 


\section{4. $\quad$ Results}

Tables 4 - 6 present the multinomial logit regression estimates (by country) for, respectively, the following child's employment/schooling choices: (a) attends school but does not work (Table 4), (b) works but does not attend school (Table 5), (c) neither attends school nor works (Table 6). As mentioned earlier, the choice category where the child attends school and works, i.e. combines schooling with employment, has been adopted as the baseline category for normalisation. The corresponding marginal probabilities are presented in Table 7.

Let us turn to the results. In all these countries, older children are more likely to combine schooling with employment than younger children. This is seen from the significantly negative estimate of the child age coefficient in each of the nine cases presented in these three tables. A comparison of the tables shows that, for each country, the absolute magnitude of the estimated age coefficient is highest in case of category (c), i.e. when the child is neither in school nor in formal wage based employment. This means that, as the child grows older, the inflow into the base category where the child combines schooling with employment is the highest from those who are engaged in neither activity. The positive age square coefficient suggests, however, that this inflow weakens in the higher age groups. The gender coefficient is positive and mostly significant suggesting that girls are more likely than boys to specialise in either schooling or in employment or do neither than in combining the two activities. Differences exist between countries with respect to the region of residence variable. For example, Table 5 shows that the urban child in Ghana is less likely to specialise in work, more likely to combine schooling with employment. The exact reverse is indicated for Peru. Table 6 shows that in Peru, with urbanisation, a child engaged in both schooling and employment tends to withdraw from both. Neither of the other two countries shares this result. 
Household composition, generally, does not exert a significant impact on the child's schooling/employment decision and, where it does, it is through the number of adults rather than the number of children in the household. This is quite surprising in that it implies that there is no quality/quantity trade off in schooling. In Peru and Ghana, though not in Pakistan, an increase in the number of adults in the household leads to children withdrawing from both schooling and employment (Table 6). The gender of the household head matters in Ghana (Tables 4, 5), but not much in the other countries.

Of particular interest in these calculations are the estimated coefficients of the poverty dummy and per adult equivalent expenditure variables. The household's poverty status is defined over non-child household income. ${ }^{8}$ In a sense this assumes that decisions on child labour are taken after adult and other non-child earnings are determined and this avoids the possible endogeneity of the poverty variable. This also underlies the "Luxury Axiom" of Basu and Van (1998) who postulate that a family will send the child to the labour market only if the family's income from non-child sources drops to very low levels. Though both the poverty dummy and per adult equivalent expenditure measure the changing economic circumstances of the household, the former refers to a discrete effect due to the household crossing the poverty line, while the latter measures the propensity of the child to change states due to small changes in the continuous expenditure variable. There are some interesting differences between the country estimates of these effects. For example, Tables 5 and 6 show that, when a Pakistani household falls into poverty, there is a strong tendency for a child that was combining schooling with employment to, either, specialise wholly in the latter, or to withdraw completely from both activity, possibly, to do domestic chores. This is consistent with the prediction of the 'Luxury Axiom' of Basu and Van (1998) and with the previous Pakistani evidence contained in Ray (2000a, 2000b). Note, however, that such a "poverty effect" on child behaviour is much weaker in the other two countries. 
The coefficients of the adult wage variables show the nature of interaction between the adult and child labour markets. As the recent analysis of Basu (2000) shows, the nature of such interaction determines the effectiveness of minimum wage legislation in reducing the incidence of child labour. The tables show that, in general, the impact of adult wages on the child's choice of categories is larger in Pakistan than in the other countries. In Pakistan, an increase in female wages leads to a significant movement from each of the three choice categories, depicted in Tables $4-6$, to the base category where the child combines schooling with employment. The movement out of category (a) ("school only") and category (c) ("neither in school nor in work"), consequent on an increase in female wages, is the disaggregated picture underlying the complementarity between the adult female and child labour markets observed in Pakistan using the binomial logit estimation procedure in Ray (2000a). Note that, unlike female wages, movement in Pakistani male wages does not have any impact on children who are exclusively in schooling (Table 4). Nor do adult wage movements in Ghana or Peru have much of an impact on children who specialise in either activity (Tables 4,5 ). It is worth emphasising from these results that the complementarity between the adult female and child labour markets is quite unique to Pakistan.

A few other interesting results are worth noting. With increasing education of the adult female in the household, there is a strong tendency for the child in Ghana, less so in Pakistan and Peru, to move out of the 'work only' and 'neither in school nor in work' categories to one where she/he combines schooling with employment (Tables 5, 6). Canagarajah and Coulombe (1997) find that mother's education increases the probability of the child's school attendance but not affect the probability of the child working. Jaffrey and Lahiri (2000) have, recently, systematically explored the link between credit markets and child labour. The Pakistani and Ghanaian data sets provide information on the amount of money lent and borrowed by the households. The effects, even when they are statistically significant, are weak. The relative 
risk ratio is unity for the credit coefficients, thus, denying a strong link between credit variables and child labour. We have not, in this study, attempted a formal test of the relationships between credit markets and child labour, discussed in Jaffrey and Lahiri (2000), since it requires an estimation framework that treats a household's credit market behaviour and child labour as jointly endogenous. While such an exercise is beyond the scope of the present study, it is an useful area for further research. Finally, community variables have significant effects in several cases. For example, the provision of improved electricity facility in Peru encourages schooling at the expense of employment (Tables 4 and 5), while the provision of improved water supply facilities in Peru encourage children to combine schooling at the expense of exclusive work or exclusive school. The community variables also exert strong impact on the child's choice of categories in Ghana. Improvements in communal facilities encourage children who are specialising in work or doing neither activity to combine schooling with employment. The Pakistani data set provides additional information on the availability of schools in the cluster of residence of the child. The availability of girls schooling and an increase in their number in the neighbourhood encourage Pakistani children who are neither in employment nor in schooling to take up both. The presence of primary schools in the neighbourhood has a similar effect in Ghana (Table 6).

Table 8 presents ordered probit estimates. The corresponding marginal probabilities are presented in Table 9. The outcomes, it may be recalled, are arranged in a decreasing order from the viewpoint of child welfare. With respect to the sign and magnitude of the marginal probabilities, Pakistan and Ghana are closer to one another than to Peru. The gender effect is particularly strong in Pakistan placing the girl child there in a position of disadvantage vis-avis Pakistani boys in trying to attain the most desirable outcome. The marginal results (Table 9) show that if we hold all other explanatory variables at their respective sample means, replacing a boy by a girl increases participation in school only by $4.1 \%$ points in Peru but 
reduces participation in school only by $16.8 \%$ points in Pakistan and $10.6 \%$ percentage points in Ghana. The poverty status of the household also has a significant affect on the probability of schooling. The ordered probit estimates show that children belonging to poor households have a significantly higher probability of attaining the worst outcome (work only). The marginal results show that children belonging to poor households have $4.6 \%, 11.2 \%$ and $12.6 \%$ lower probability of the attaining the best outcome (school only) in Peru, Pakistan and Ghana respectively) while they have a $0.7 \%, 7.8 \%$ and a $6.3 \%$ higher probability of attaining the worst outcome (work only) in Peru, Pakistan and Ghana respectively. In Pakistan and Ghana (but not in Peru) household poverty reduces the probability of child participation in the school and work category also. An increase in the number of girls' schools in the cluster in Pakistan or the presence of primary schools in the neighbourhood in Ghana has strong beneficial effects in helping the child attain the most desirable outcome. The rest of the results are quite similar to those obtained from the multinomial logit estimates and will not be discussed in detail.

\section{Conclusion}

The issue of child labour, which is at the heart of the development literature today, has attracted considerable attention in recent years. Notwithstanding continuous and significant reductions during much of the previous century, the child labour force is still large enough to be of serious concern. Strategies aimed at reducing or eliminating child labour need, for their effectiveness, identification of its key determinants. A comparative study of child labour on disparate data sets, using a common estimation framework, is therefore of considerable policy importance. Such a study has been the principal motivation of this exercise. This paper uses high quality, comparable data from countries located in different continents to compare and analyse the phenomenon of child labour in these regions. The chosen countries, Peru, Pakistan 
and Ghana, provide considerable heterogeneity through their data sets to make the results of this study significant.

The central message of this paper is that one needs to recognise the regional diversity in the nature of child labour in formulating policies to reduce or eliminate it. For example, while improved provision of good quality schools helps to reduce child labour everywhere, such schools need to be located near places of child employment in Peru, and in the residential neighbourhood in Pakistan. This recognises the fact that, while Peruvian children tend to combine schooling with employment, large numbers of Pakistani children, especially girls, are at home doing neither. The Pakistani results also highlight the need to target households living below the poverty line and, especially, girls in such households for effective child welfare enhancing policies. Moreover, in Pakistan, steps need to be directed at breaking the close nexus that exists there between the adult female and the child labour markets.

While the overall goal of such policies must be to move the child from a "work only" to "school only" status, such a strategy can only be a long term one. In the short run, any policy that moves a child from a "work only" or "neither in work nor in school" status to one where she/he combines schooling with employment must be considered to be a significant success. This prompts the need to widen the definition of child work to include domestic hours and other forms of non-remunerative child work. 
Table 1: Description of Variables

\begin{tabular}{|c|c|}
\hline Variable & Description \\
\hline AGE & Age of Child \\
\hline AGE2 & Age of Child Squared \\
\hline GIRL $^{*}$ & Gender of Child ( 1 = girl, 0 otherwise) \\
\hline URBAN $^{*}$ & Region of Residence $(1=$ urban, $0=$ rural $)$ \\
\hline NCHILD & Number of Children in Household \\
\hline NADULT & Number of Adults in Household \\
\hline AMOUNTL & Amount Lent (Pakistan, Ghana) \\
\hline AMOUNTB & Amount Borrowed (Pakistan, Ghana) \\
\hline $\mathrm{FHH}^{*}$ & Gender of Household Head $(1=$ female, $0=$ male $)$ \\
\hline HEADAGE & Age of Household Head \\
\hline LANGHH $^{*}$ & Language of Household Head ( 1 = Dominant Language, 0 otherwise) \\
\hline MAXFEMED & Number of years of Schooling of the Most Educated Female in the Household \\
\hline $\mathrm{POV}^{*}$ & $=1$ if Household is Poor, 0 otherwise \\
\hline PCEX & Expenditure Per Equivalent Adult \\
\hline MAXMWAGE & Maximum Wage Earned by Male Members in the Household \\
\hline MAXFWAGE & Maximum Wage Earned by Female Members in the Household \\
\hline MAXFWAGE2 & Maximum Female Wage Squared \\
\hline WATER $1^{*}$ & $=1$ If Household has Access to Piped Water, 0 otherwise (Pakistan only) \\
\hline ROAD & $=1$ if Road is available, 0 otherwise (Pakistan only) \\
\hline CLOSEDDR $^{*}$ & $=1$ if Closed Drains near House, 0 otherwise (Pakistan only) \\
\hline DISPOS $1^{*}$ & $=1$ if Household has no Waste Disposal Method, 0 otherwise (Pakistan only) \\
\hline DWATER ${ }^{*}$ & $\begin{array}{l}=1 \text { if the Main Source of Drinking Water is River, Lake, Spring or Pond, } 0 \text { otherwise } \\
\text { (Ghana only) }\end{array}$ \\
\hline TOILET $^{*}$ & $=1$ if Toilet Facility for the Household is Pit Latrine, 0 otherwise (Ghana only) \\
\hline LIGHT $^{*}$ & $\begin{array}{l}=1 \text { if Main Source of Lighting for the Household is Kerosene, Oil or Gas Lamp, } 0 \\
\text { otherwise (Ghana only) }\end{array}$ \\
\hline ELECTR $^{*}$ & $=1$ if Main Source of Illumination is Electricity, 0 otherwise (Peru only) \\
\hline 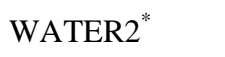 & $=1$ if Water Supply is Inside the House, 0 otherwise (Peru only) \\
\hline WATERC $^{*}$ & $=1$ if water is not Contaminated, 0 otherwise (Peru only) \\
\hline $\operatorname{DISPOS} 2^{*}$ & $\begin{array}{l}=1 \text { if Main Form of Waste Disposal is Public Connection Inside House, } 0 \text { otherwise (Peru } \\
\text { only) }\end{array}$ \\
\hline BOYSC & Number of Boys Schools in Cluster (Pakistan only) \\
\hline GIRLSC & Number of Girls Schools in Cluster (Pakistan only) \\
\hline COEDSC & Number of Coeducation Schools in Cluster (Pakistan only) \\
\hline BOYCLOS & $=0$ if any Boys School in Cluster is Closed, 1 otherwise (Pakistan only) \\
\hline GIRLCLOS $^{*}$ & $=0$ if any Girls School in Cluster is Closed, 1 otherwise (Pakistan only) \\
\hline COEDCLOS $^{*}$ & $=0$ if any Coeducation School in Cluster is Closed, 1 otherwise (Pakistan only) \\
\hline PRIMYES & $=1$ if there is any Primary School in Cluster, 0 otherwise (Ghana only) \\
\hline
\end{tabular}

Note: * denotes a dummy variable. 
Table 2A: Percentage of Children Who Attend School and Do Not Work

\begin{tabular}{|c|c|c|c|c|c|c|c|c|c|c|c|c|}
\hline \multirow[b]{2}{*}{ Age } & \multicolumn{4}{|c|}{ Peru } & \multicolumn{4}{|c|}{ Pakistan } & \multicolumn{4}{|c|}{ Ghana } \\
\hline & Overall & Boys & Girls & Difference & Overall & Boys & Girls & Difference & Overall & Boys & Girls & Difference \\
\hline 6 & 0.797 & 0.817 & 0.774 & .043 & - & - & - & - & 0.5 & 0.504 & 0.496 & 0.008 \\
\hline 7 & 0.808 & 0.792 & 0.825 & -.033 & - & - & - & - & 0.619 & 0.647 & 0.594 & 0.053 \\
\hline 8 & 0.816 & 0.788 & 0.840 & -.052 & - & - & - & - & 0.559 & 0.591 & 0.524 & 0.067 \\
\hline 9 & 0.796 & 0.777 & 0.814 & -.037 & - & - & - & - & 0.614 & 0.631 & 0.596 & 0.035 \\
\hline 10 & 0.707 & 0.679 & 0.735 & -.056 & 0.591 & 0.698 & 0.478 & $0.220^{\mathrm{a}}$ & 0.583 & 0.609 & 0.554 & 0.055 \\
\hline 11 & 0.704 & 0.674 & 0.738 & -.064 & 0.637 & 0.734 & 0.522 & $0.212^{\mathrm{a}}$ & 0.518 & 0.535 & 0.500 & 0.035 \\
\hline 12 & 0.649 & 0.594 & 0.703 & $-.109^{a}$ & 0.544 & 0.627 & 0.443 & $0.184^{\mathrm{a}}$ & 0.471 & 0.496 & 0.438 & 0.058 \\
\hline 13 & 0.662 & 0.654 & 0.669 & -.015 & 0.499 & 0.577 & 0.428 & $0.149^{\mathrm{a}}$ & 0.404 & 0.420 & 0.385 & 0.035 \\
\hline 14 & 0.559 & 0.494 & 0.623 & $-.129^{\mathrm{a}}$ & 0.439 & 0.527 & 0.356 & $0.171^{\mathrm{a}}$ & 0.397 & 0.381 & 0.417 & -0.036 \\
\hline 15 & 0.523 & 0.472 & 0.574 & $-.102^{\mathrm{a}}$ & 0.376 & 0.450 & 0.295 & $0.155^{\mathrm{a}}$ & 0.315 & 0.387 & 0.241 & $0.146^{\mathrm{a}}$ \\
\hline 16 & 0.490 & 0.475 & 0.505 & -.030 & 0.336 & 0.402 & 0.270 & $0.132^{\mathrm{a}}$ & 0.266 & 0.311 & 0.222 & $0.089^{\mathrm{a}}$ \\
\hline 17 & 0.365 & 0.311 & 0.416 & $-.105^{\mathrm{a}}$ & 0.324 & 0.358 & 0.278 & $0.080 \mathrm{a}$ & 0.220 & 0.254 & 0.179 & 0.075 \\
\hline
\end{tabular}

Note: ${ }^{a}$ denotes that the gender difference is statistically significant at $5 \%$ significance level. 
Table 2B: Percentage of Children Who Attend School and Work

\begin{tabular}{|c|c|c|c|c|c|c|c|c|c|c|c|c|}
\hline & \multicolumn{4}{|c|}{ Peru } & \multicolumn{4}{|c|}{ Pakistan } & \multicolumn{4}{|c|}{ Ghana } \\
\hline Age & Overall & Boys & Girls & Difference & Overall & Boys & Girls & Difference & Overall & Boys & Girls & Difference \\
\hline 6 & 0.081 & 0.071 & 0.092 & -0.021 & - & - & - & - & - & - & - & - \\
\hline 7 & 0.115 & 0.121 & 0.109 & 0.012 & - & - & - & - & 0.032 & 0.027 & 0.036 & -0.009 \\
\hline 8 & 0.123 & 0.156 & 0.096 & $0.060^{\mathrm{a}}$ & - & - & - & - & 0.066 & 0.087 & 0.044 & $0.043^{\mathrm{a}}$ \\
\hline 9 & 0.177 & 0.186 & 0.169 & 0.017 & - & - & - & - & 0.087 & 0.097 & 0.076 & 0.021 \\
\hline 10 & 0.237 & 0.281 & 0.196 & $0.085^{\mathrm{a}}$ & 0.054 & 0.074 & 0.033 & $0.041^{\mathrm{a}}$ & 0.125 & 0.133 & 0.116 & 0.017 \\
\hline 11 & 0.253 & 0.302 & 0.200 & $0.102^{\mathrm{a}}$ & 0.060 & 0.088 & 0.027 & $0.061^{\mathrm{a}}$ & 0.191 & 0.221 & 0.159 & 0.017 \\
\hline 12 & 0.288 & 0.338 & 0.238 & $0.100^{\mathrm{a}}$ & 0.081 & 0.108 & 0.048 & $0.060^{\mathrm{a}}$ & 0.161 & 0.176 & 0.143 & 0.033 \\
\hline 13 & 0.242 & 0.290 & 0.199 & $0.091^{\mathrm{a}}$ & 0.083 & 0.147 & 0.025 & $0.122^{\mathrm{a}}$ & 0.199 & 0.203 & 0.195 & 0.008 \\
\hline 14 & 0.310 & 0.376 & 0.246 & $0.130^{\mathrm{a}}$ & 0.088 & 0.143 & 0.035 & $0.108^{\mathrm{a}}$ & 0.212 & 0.274 & 0.129 & $0.145^{\mathrm{a}}$ \\
\hline 15 & 0.294 & 0.377 & 0.213 & $0.164^{\mathrm{a}}$ & 0.081 & 0.119 & 0.040 & $0.079^{\mathrm{a}}$ & 0.202 & 0.247 & 0.155 & $0.092^{\mathrm{a}}$ \\
\hline 16 & 0.267 & 0.337 & 0.201 & $0.136^{\mathrm{a}}$ & 0.058 & 0.105 & 0.011 & $0.094^{\mathrm{a}}$ & 0.201 & 0.220 & 0.182 & 0.038 \\
\hline 17 & 0.203 & 0.302 & 0.111 & $0.191^{\mathrm{a}}$ & 0.077 & 0.130 & 0.005 & $0.125^{\mathrm{a}}$ & 0.150 & 0.204 & 0.080 & $0.124^{\mathrm{a}}$ \\
\hline
\end{tabular}

Note: ${ }^{\text {a }}$ denotes that the gender difference is statistically significant at $5 \%$ significance level. 
Table 2C: Percentage of Children Who Do Not Attend School but Work

\begin{tabular}{|c|c|c|c|c|c|c|c|c|c|c|c|c|}
\hline \multirow[b]{2}{*}{ Age } & \multicolumn{4}{|c|}{ Peru } & \multicolumn{4}{|c|}{ Pakistan } & \multicolumn{4}{|c|}{ Ghana } \\
\hline & Overall & Boys & Girls & Difference & Overall & Boys & Girls & Difference & Overall & Boys & Girls & Difference \\
\hline 6 & 0.014 & 0.007 & 0.021 & -0.014 & - & - & - & - & - & - & - & - \\
\hline 7 & 0.010 & 0.017 & 0.004 & 0.013 & - & - & - & - & 0.021 & 0.036 & 0.008 & $0.028^{\mathrm{a}}$ \\
\hline 8 & 0.016 & 0.013 & 0.018 & -0.005 & - & - & - & - & 0.045 & 0.045 & 0.044 & 0.001 \\
\hline 9 & 0.002 & 0.005 & 0.000 & 0.005 & - & - & - & - & 0.048 & 0.055 & 0.040 & 0.015 \\
\hline 10 & 0.011 & 0.014 & 0.009 & 0.005 & 0.113 & 0.074 & 0.154 & $-0.080^{\mathrm{a}}$ & 0.083 & 0.089 & 0.076 & 0.013 \\
\hline 11 & 0.011 & 0.008 & 0.013 & -0.005 & 0.118 & 0.073 & 0.169 & $-0.096^{\mathrm{a}}$ & 0.119 & 0.111 & 0.128 & 0.017 \\
\hline 12 & 0.030 & 0.038 & 0.021 & 0.017 & 0.161 & 0.147 & 0.178 & -0.031 & 0.148 & 0.149 & 0.148 & 0.001 \\
\hline 13 & 0.042 & 0.023 & 0.059 & $-0.036^{\mathrm{a}}$ & 0.171 & 0.154 & 0.188 & -0.034 & 0.181 & 0.232 & 0.118 & $0.114^{\mathrm{a}}$ \\
\hline 14 & 0.075 & 0.089 & 0.061 & 0.028 & 0.234 & 0.218 & 0.249 & -0.031 & 0.204 & 0.163 & 0.258 & $-0.095^{\mathrm{a}}$ \\
\hline 15 & 0.100 & 0.104 & 0.097 & 0.007 & 0.269 & 0.279 & 0.258 & 0.021 & 0.257 & 0.216 & 0.299 & $-0.083^{\mathrm{a}}$ \\
\hline 16 & 0.113 & 0.109 & 0.117 & -0.008 & 0.330 & 0.407 & 0.253 & $0.154^{\mathrm{a}}$ & 0.300 & 0.259 & 0.341 & -0.082 \\
\hline 17 & 0.182 & 0.236 & 0.132 & $0.104^{\mathrm{a}}$ & 0.312 & 0.354 & 0.254 & $0.100^{\mathrm{a}}$ & 0.343 & 0.324 & 0.366 & -0.042 \\
\hline
\end{tabular}

Note: ${ }^{\text {a }}$ denotes that the gender difference is statistically significant at $5 \%$ significance level. 
Table 2D: Percentage of Children Who Neither Attend School Nor Work

\begin{tabular}{|c|c|c|c|c|c|c|c|c|c|c|c|c|}
\hline \multirow[b]{2}{*}{ Age } & \multicolumn{4}{|c|}{ Peru } & \multicolumn{4}{|c|}{ Pakistan } & \multicolumn{4}{|c|}{ Ghana } \\
\hline & Overall & Boys & Girls & Difference & Overall & Boys & Girls & Difference & Overall & Boys & Girls & Difference \\
\hline 6 & 0.019 & 0.105 & 0.113 & -0.008 & - & - & - & - & 0.500 & 0.496 & 0.504 & -0.008 \\
\hline 7 & 0.066 & 0.071 & 0.061 & 0.010 & - & - & - & - & 0.328 & 0.290 & 0.363 & -0.07 \\
\hline 8 & 0.045 & 0.043 & 0.046 & -0.003 & - & - & - & - & 0.330 & 0.277 & 0.388 & $-0.011^{\mathrm{a}}$ \\
\hline 9 & 0.024 & 0.032 & 0.017 & 0.015 & - & - & - & - & 0.251 & 0.216 & 0.2887 & -0.071 \\
\hline 10 & 0.044 & 0.027 & 0.061 & -0.034 & 0.242 & 0.153 & 0.335 & $-0.182^{\mathrm{a}}$ & 0.210 & 0.169 & 0.254 & $-0.085^{\mathrm{a}}$ \\
\hline 11 & 0.032 & 0.017 & 0.049 & $-0.032^{\mathrm{a}}$ & 0.186 & 0.105 & 0.282 & $-0.177^{\mathrm{a}}$ & 0.173 & 0.134 & 0.213 & -0.079 \\
\hline 12 & 0.039 & 0.030 & 0.038 & -0.008 & 0.214 & 0.118 & 0.330 & $-0.212^{\mathrm{a}}$ & 0.219 & 0.179 & 0.271 & $-0.092^{\mathrm{a}}$ \\
\hline 13 & 0.053 & 0.033 & 0.073 & $-0.040^{\mathrm{a}}$ & 0.246 & 0.123 & 0.359 & $-0.236^{\mathrm{a}}$ & 0.215 & 0.145 & 0.302 & $-0.157^{\mathrm{a}}$ \\
\hline 14 & 0.056 & 0.042 & 0.070 & -0.028 & 0.239 & 0.112 & 0.361 & $-0.249^{\mathrm{a}}$ & 0.188 & 0.181 & 0.196 & -0.015 \\
\hline 15 & 0.082 & 0.047 & 0.116 & $0.031^{\mathrm{a}}$ & 0.274 & 0.152 & 0.407 & $-0.255^{\mathrm{a}}$ & 0.226 & 0.149 & 0.305 & $-0.156^{\mathrm{a}}$ \\
\hline 16 & 0.130 & 0.079 & 0.178 & -0.108 & 0.277 & 0.086 & 0.465 & $-0.379^{\mathrm{a}}$ & 0.232 & 0.209 & 0.256 & -0.047 \\
\hline 17 & 0.250 & 0.151 & 0.342 & $-0.191^{a}$ & 0.287 & 0.158 & 0.464 & $-0.306^{\mathrm{a}}$ & 0.287 & 0.218 & 0.375 & $-0.157^{\mathrm{a}}$ \\
\hline
\end{tabular}

Note: ${ }^{\text {a }}$ denotes that the gender difference is statistically significant at $5 \%$ significance level. 
Table 3: Percentage Share of Income from Child Labour

\begin{tabular}{|l|c|c|c|}
\hline & All & Boys & Girls \\
\hline Peru & 9.77 & 14.11 & 4.77 \\
Only Work & 3.58 & 3.79 & 3.26 \\
\hline Path Work \& School & & & \\
Only Work & 23.37 & 30.33 & 16.05 \\
Both Work \& School & 10.18 & 8.56 & 10.57 \\
& & & \\
\hline Ghana & 30.14 & 30.33 & 31.22 \\
Only Work & 19.87 & 25.77 & 13.96 \\
Both Work \& School & & & \\
\hline
\end{tabular}


Table 4: Multinomial Logit Estimates for Category ${ }^{\mathrm{a}}$ : School Only

\begin{tabular}{|c|c|c|c|c|c|c|}
\hline \multirow{2}{*}{ Variable } & \multicolumn{2}{|c|}{ Peru } & \multicolumn{2}{|c|}{ Pakistan } & \multicolumn{2}{|c|}{ Ghana } \\
\hline & $\begin{array}{l}\text { Coefficient } \\
\text { Estimate }^{b}\end{array}$ & $\begin{array}{c}\text { Relative } \\
\text { Risk Ratio }\end{array}$ & $\begin{array}{l}\text { Coefficient } \\
\text { Estimate }^{b}\end{array}$ & $\begin{array}{c}\text { Relative } \\
\text { Risk Ratio }\end{array}$ & $\begin{array}{l}\text { Coefficient } \\
\text { Estimate }^{b}\end{array}$ & $\begin{array}{c}\text { Relative } \\
\text { Risk Ratio }\end{array}$ \\
\hline AGE & $\begin{array}{l}-0.432^{c} \\
(0.097)\end{array}$ & 0.649 & $\begin{array}{l}-0.692^{c} \\
(0.350)\end{array}$ & 0.501 & $\begin{array}{c}-1.052^{c} \\
(.129)\end{array}$ & .349 \\
\hline AGE2 & $\begin{array}{c}0.007 \\
(0.004)\end{array}$ & 1.007 & $\begin{array}{c}0.018 \\
(0.013)\end{array}$ & 1.018 & $\begin{array}{l}0.032^{\mathrm{c}} \\
(0.005)\end{array}$ & 1.033 \\
\hline GIRL & $\begin{array}{l}0.745^{\mathrm{c}} \\
(0.083)\end{array}$ & 2.107 & $\begin{array}{l}0.910^{c} \\
(0.135)\end{array}$ & 2.485 & $\begin{array}{l}0.240^{\mathrm{c}} \\
(0.100)\end{array}$ & 1.272 \\
\hline URBAN & $\begin{array}{l}1.782^{c} \\
(0.128)\end{array}$ & 5.944 & $\begin{array}{l}1.123^{\mathrm{c}} \\
(0.292)\end{array}$ & 3.075 & $\begin{array}{c}0.116 \\
(0.147)\end{array}$ & 1.123 \\
\hline NCHILD & $\begin{array}{c}-0.051 \\
(0.026)\end{array}$ & 0.951 & $\begin{array}{l}-0.015 \\
(0.021)\end{array}$ & 0.985 & $\begin{array}{l}-0.043^{c} \\
(0.022)\end{array}$ & 0.958 \\
\hline NADULT & $\begin{array}{l}0.106^{\mathrm{c}} \\
(0.038)\end{array}$ & 1.112 & $\begin{array}{l}0.081^{\mathrm{c}} \\
(0.029)\end{array}$ & 1.085 & $\begin{array}{c}0.032 \\
(0.041)\end{array}$ & 1.033 \\
\hline AMOUNTL & - & - & $\begin{array}{l}-0.000^{c} \\
(0.000)\end{array}$ & 1.000 & $\begin{array}{l}-0.000^{c} \\
(0.000)\end{array}$ & 1.000 \\
\hline AMOUNTB & - & - & $\begin{array}{c}-0.000 \\
(0.000)\end{array}$ & 1.000 & $\begin{array}{l}0.000^{c} \\
(0.000)\end{array}$ & 1.000 \\
\hline $\mathrm{FHH}$ & $\begin{array}{c}0.030 \\
(0.170)\end{array}$ & 1.031 & $\begin{array}{l}-0.411 \\
(0.377)\end{array}$ & 0.663 & $\begin{array}{l}0.337^{\mathrm{c}} \\
(0.112)\end{array}$ & 1.400 \\
\hline HEADAGE & $\begin{array}{c}-0.001 \\
(0.004)\end{array}$ & 0.999 & $\begin{array}{c}0.000 \\
(0.005)\end{array}$ & 1.00 & $\begin{array}{l}-0.006 \\
(0.004)\end{array}$ & 0.994 \\
\hline LANGHH & - & - & $\begin{array}{c}0.149 \\
(0.170)\end{array}$ & 1.161 & $\begin{array}{l}-0.431^{c} \\
(0.120)\end{array}$ & 0.650 \\
\hline MAXFEMED & $\begin{array}{l}0.037^{\mathrm{c}} \\
(0.011)\end{array}$ & 1.037 & $\begin{array}{l}0.070^{\mathrm{c}} \\
(0.018)\end{array}$ & 1.072 & $\begin{array}{c}0.007 \\
(0.011)\end{array}$ & 1.007 \\
\hline MAXMWAGE & $\begin{array}{c}0.040 \\
(0.025)\end{array}$ & 1.041 & $\begin{array}{c}0.000 \\
(0.004)\end{array}$ & 1.000 & $\begin{array}{c}0.000 \\
(0.000)\end{array}$ & 1.000 \\
\hline MAXFWAGE & $\begin{array}{l}-0.008 \\
(0.032)\end{array}$ & 0.992 & $\begin{array}{l}-0.103^{c} \\
(0.016)\end{array}$ & 0.902 & $\begin{array}{c}0.000 \\
(0.000)\end{array}$ & 1.000 \\
\hline MAXFWAGE2 & $\begin{array}{c}0.000 \\
(0.000)\end{array}$ & 1.000 & $\begin{array}{c}0.001 \\
(0.000)\end{array}$ & 1.001 & $\begin{array}{c}0.000 \\
(0.000)\end{array}$ & 1.000 \\
\hline POV & $\begin{array}{l}-0.048 \\
(0.110)\end{array}$ & 0.953 & $\begin{array}{c}0.256 \\
(0.215)\end{array}$ & 1.292 & $\begin{array}{l}-0.523^{c} \\
(0.185)\end{array}$ & 0.593 \\
\hline PCEX & $\begin{array}{l}0.000^{c} \\
(0.000)\end{array}$ & 1.000 & $\begin{array}{c}0.000 \\
(0.000)\end{array}$ & 1.000 & $\begin{array}{c}0.000 \\
(0.000)\end{array}$ & 1.000 \\
\hline WATER 1 & - & - & $\begin{array}{l}0.353^{c} \\
(0.135)\end{array}$ & 1.423 & - & - \\
\hline ROAD & - & - & $\begin{array}{c}0.209 \\
(0.125)\end{array}$ & 1.232 & - & - \\
\hline CLOSEDDR & - & - & $\begin{array}{c}0.244 \\
(0.184)\end{array}$ & 1.277 & - & - \\
\hline DISPOS1 & - & - & $\begin{array}{c}0.037 \\
(0.177)\end{array}$ & 1.037 & - & - \\
\hline
\end{tabular}


Table 4 (Continued)

\begin{tabular}{|c|c|c|c|c|c|c|}
\hline \multirow{2}{*}{ Variable } & \multicolumn{2}{|c|}{ Peru } & \multicolumn{2}{|c|}{ Pakistan } & \multicolumn{2}{|c|}{ Ghana } \\
\hline & $\begin{array}{l}\text { Coefficient } \\
\text { Estimate }^{b}\end{array}$ & $\begin{array}{c}\text { Relative } \\
\text { Risk Ratio }\end{array}$ & $\begin{array}{c}\text { Coefficient } \\
\text { Estimate }^{b}\end{array}$ & $\begin{array}{c}\text { Relative } \\
\text { Risk Ratio }\end{array}$ & $\begin{array}{l}\text { Coefficient } \\
\text { Estimate }^{b}\end{array}$ & $\begin{array}{c}\text { Relative } \\
\text { Risk Ratio }\end{array}$ \\
\hline DWATER & - & - & - & - & $\begin{array}{l}-0.668^{c} \\
(0.120)\end{array}$ & 0.513 \\
\hline TOILET & - & - & - & - & $\begin{array}{l}-0.768^{c} \\
(0.119)\end{array}$ & 0.464 \\
\hline LIGHT & - & - & - & - & $\begin{array}{l}-0.150 \\
(0.171)\end{array}$ & 0.861 \\
\hline ELECTR & $\begin{array}{c}0.008 \\
(0.191)\end{array}$ & 1.008 & - & - & - & - \\
\hline WATER2 & $\begin{array}{l}-0.563^{c} \\
(0.174)\end{array}$ & 0.569 & - & - & - & - \\
\hline WATERC & $\begin{array}{c}0.138 \\
(0.130)\end{array}$ & 1.148 & - & - & - & - \\
\hline DISPOS2 & $\begin{array}{c}0.116 \\
(0.214)\end{array}$ & 1.123 & - & - & - & - \\
\hline BOYSC & - & - & $\begin{array}{l}-0.012 \\
(0.035)\end{array}$ & 0.988 & - & - \\
\hline GIRLSC & - & - & $\begin{array}{l}-0.306^{c} \\
(0.065)\end{array}$ & 0.736 & - & - \\
\hline COEDSC & - & - & $\begin{array}{l}-0.057 \\
(0.053)\end{array}$ & 0.945 & - & - \\
\hline BOYCLOS & - & - & $\begin{array}{l}-0.260 \\
(0.273)\end{array}$ & 1.297 & - & - \\
\hline GIRLCLOS & - & - & $\begin{array}{l}-0.543^{c} \\
(0.245)\end{array}$ & 1.721 & - & - \\
\hline COEDCLOS & - & - & $\begin{array}{c}0.050 \\
(0.182)\end{array}$ & 0.951 & - & - \\
\hline PRIMYES & - & - & - & - & $\begin{array}{l}-0.364^{c} \\
(0.121)\end{array}$ & 0.695 \\
\hline
\end{tabular}

Note: $\quad{ }^{\mathrm{a}}$ The normalised category is: both school and work.

${ }^{\mathrm{b}}$ (Heteroskedasticity consistent) standard errors in brackets.

${ }^{\mathrm{c}}$ Denotes significance at $5 \%$ significance level. 
Table 5: Multinomial Logit Estimates for Category ${ }^{\mathrm{a}}$ : Work Only

\begin{tabular}{|c|c|c|c|c|c|c|}
\hline \multirow{2}{*}{ Variable } & \multicolumn{2}{|c|}{ Peru } & \multicolumn{2}{|c|}{ Pakistan } & \multicolumn{2}{|c|}{ Ghana } \\
\hline & $\begin{array}{l}\text { Coefficient } \\
\text { Estimate }^{b}\end{array}$ & $\begin{array}{c}\text { Relative } \\
\text { Risk Ratio }\end{array}$ & $\begin{array}{l}\text { Coefficient } \\
\text { Estimate }^{b}\end{array}$ & $\begin{array}{c}\text { Relative } \\
\text { Risk Ratio }\end{array}$ & $\begin{array}{l}\text { Coefficient } \\
\text { Estimate }^{b}\end{array}$ & $\begin{array}{c}\text { Relative } \\
\text { Risk Ratio }\end{array}$ \\
\hline AGE & $\begin{array}{l}-0.805^{\mathrm{c}} \\
(0.225)\end{array}$ & 0.447 & $\begin{array}{c}-0.464 \\
(0.373)\end{array}$ & 0.629 & $\begin{array}{c}-0.433^{c} \\
(.176)\end{array}$ & 0.649 \\
\hline AGE2 & $\begin{array}{l}0.043^{\mathrm{c}} \\
(0.009)\end{array}$ & 1.044 & $\begin{array}{c}0.024 \\
(0.014)\end{array}$ & 1.025 & $\begin{array}{l}0.025^{\mathrm{c}} \\
(0.007)\end{array}$ & 1.025 \\
\hline GIRL & $\begin{array}{c}0.128 \\
(0.152)\end{array}$ & 1.137 & $\begin{array}{l}1.547^{\mathrm{c}} \\
(0.138)\end{array}$ & 4.699 & $\begin{array}{l}0.828^{\mathrm{c}} \\
(0.125)\end{array}$ & 2.289 \\
\hline URBAN & $\begin{array}{c}1.727^{\mathrm{c}} \\
(0.255)\end{array}$ & 2.069 & $\begin{array}{c}0.405 \\
(0.302)\end{array}$ & 1.500 & $\begin{array}{l}-0.589^{c} \\
(0.202)\end{array}$ & 0.555 \\
\hline NCHILD & $\begin{array}{l}-0.036 \\
(0.049)\end{array}$ & 0.965 & $\begin{array}{c}0.011 \\
(0.022)\end{array}$ & 1.011 & $\begin{array}{c}-0.038 \\
(0.026)\end{array}$ & 0.962 \\
\hline NADULT & $\begin{array}{c}0.106 \\
(0.058)\end{array}$ & 1.111 & $\begin{array}{l}-0.075^{\mathrm{c}} \\
(0.033)\end{array}$ & 0.928 & $\begin{array}{l}0.118^{\mathrm{c}} \\
(0.048)\end{array}$ & 1.125 \\
\hline AMOUNTL & - & - & $\begin{array}{l}-0.000 \\
(0.000)\end{array}$ & 1.000 & $\begin{array}{l}-0.000 \\
(0.000)\end{array}$ & 1.000 \\
\hline AMOUNTB & - & - & $\begin{array}{l}-0.000 \\
(0.000)\end{array}$ & 1.000 & $\begin{array}{c}0.000 \\
(0.000)\end{array}$ & 1.000 \\
\hline $\mathrm{FHH}$ & $\begin{array}{l}0.554^{\mathrm{c}} \\
(0.282)\end{array}$ & 1.740 & $\begin{array}{l}-0.259 \\
(0.406)\end{array}$ & 0.772 & $\begin{array}{l}-0.360^{c} \\
(0.152)\end{array}$ & 0.698 \\
\hline HEADAGE & $\begin{array}{c}0.010 \\
(0.008)\end{array}$ & 1.010 & $\begin{array}{c}0.006 \\
(0.005)\end{array}$ & 1.006 & $\begin{array}{l}-0.004 \\
(0.005)\end{array}$ & 0.996 \\
\hline LANGHH & - & - & $\begin{array}{l}-0.141 \\
(0.182)\end{array}$ & 0.869 & $\begin{array}{l}-0.535^{\mathrm{c}} \\
(0.171)\end{array}$ & 0.585 \\
\hline MAXFEMED & $\begin{array}{l}-0.070^{c} \\
(0.021)\end{array}$ & 0.932 & $\begin{array}{l}-0.081^{\mathrm{c}} \\
(0.022)\end{array}$ & 0.922 & $\begin{array}{l}-0.206^{c} \\
(0.017)\end{array}$ & 0.814 \\
\hline MAXMWAGE & $\begin{array}{c}-0.038 \\
(0.050)\end{array}$ & 0.963 & $\begin{array}{l}-0.014^{\mathrm{c}} \\
(0.005)\end{array}$ & 0.986 & $\begin{array}{c}0.000 \\
(0.000)\end{array}$ & 1.000 \\
\hline MAXFWAGE & $\begin{array}{l}-0.061 \\
(0.070)\end{array}$ & 0.941 & $\begin{array}{l}-0.033^{c} \\
(0.016)\end{array}$ & 0.967 & $\begin{array}{l}-0.000 \\
(0.000)\end{array}$ & 1.000 \\
\hline MAXFWAGE2 & $\begin{array}{c}0.001 \\
(0.001)\end{array}$ & 1.001 & $\begin{array}{l}0.001^{\mathrm{c}} \\
(0.000)\end{array}$ & 1.001 & $\begin{array}{c}0.000 \\
(0.000)\end{array}$ & 1.000 \\
\hline POV & $\begin{array}{c}0.154 \\
(0.195)\end{array}$ & 1.166 & $\begin{array}{l}0.743^{\mathrm{c}} \\
(0.225)\end{array}$ & 2.102 & $\begin{array}{c}0.331 \\
(0.198)\end{array}$ & 1.393 \\
\hline PCEX & $\begin{array}{c}0.000 \\
(0.000)\end{array}$ & 1.000 & $\begin{array}{l}-0.000^{c} \\
(0.000)\end{array}$ & 1.000 & $\begin{array}{c}0.000 \\
(0.000)\end{array}$ & 1.000 \\
\hline WATER1 & - & - & $\begin{array}{l}-0.136 \\
(0.147)\end{array}$ & 0.873 & - & - \\
\hline ROAD & - & - & $\begin{array}{l}-0.136 \\
(0.134)\end{array}$ & 0.873 & - & - \\
\hline CLOSEDDR & - & - & $\begin{array}{l}-0.038 \\
(0.203)\end{array}$ & 0.963 & - & - \\
\hline DISPOS1 & - & - & $\begin{array}{c}0.224 \\
(0.193)\end{array}$ & 1.251 & - & - \\
\hline
\end{tabular}


Table 5 (Continued)

\begin{tabular}{|c|c|c|c|c|c|c|}
\hline \multirow{2}{*}{ Variable } & \multicolumn{2}{|c|}{ Peru } & \multicolumn{2}{|c|}{ Pakistan } & \multicolumn{2}{|c|}{ Ghana } \\
\hline & $\begin{array}{l}\text { Coefficient } \\
\text { Estimate }^{b}\end{array}$ & $\begin{array}{c}\text { Relative } \\
\text { Risk Ratio }\end{array}$ & $\begin{array}{c}\text { Coefficient } \\
\text { Estimate }^{b}\end{array}$ & $\begin{array}{c}\text { Relative } \\
\text { Risk Ratio }\end{array}$ & $\begin{array}{l}\text { Coefficient } \\
\text { Estimate }^{b}\end{array}$ & $\begin{array}{c}\text { Relative } \\
\text { Risk Ratio }\end{array}$ \\
\hline DWATER & - & - & - & - & $\begin{array}{l}-0.615^{\mathrm{c}} \\
(0.138)\end{array}$ & 0.541 \\
\hline TOILET & - & - & - & - & $\begin{array}{l}-0.963^{c} \\
(0.135)\end{array}$ & 0.382 \\
\hline LIGHT & - & - & - & - & $\begin{array}{l}-0.028 \\
(0.210)\end{array}$ & 0.973 \\
\hline ELECTR & $\begin{array}{l}-0.947^{\mathrm{c}} \\
(0.245)\end{array}$ & 0.388 & - & - & - & - \\
\hline WATER2 & $\begin{array}{l}-0.602^{c} \\
(0.211)\end{array}$ & 0.548 & - & - & - & - \\
\hline WATERC & $\begin{array}{l}-0.105 \\
(0.153)\end{array}$ & 0.901 & - & - & - & - \\
\hline DISPOS2 & $\begin{array}{c}0.110 \\
(0.310)\end{array}$ & 1.116 & - & - & - & - \\
\hline BOYSC & - & - & $\begin{array}{c}0.009 \\
(0.034)\end{array}$ & 1.009 & - & - \\
\hline GIRLSC & - & - & $\begin{array}{l}-0.183^{c} \\
(0.058)\end{array}$ & 0.833 & - & - \\
\hline COEDSC & - & - & $\begin{array}{l}0.112^{\mathrm{c}} \\
(0.049)\end{array}$ & 1.118 & - & - \\
\hline BOYCLOS & - & - & $\begin{array}{l}-0.011 \\
(0.268)\end{array}$ & 1.011 & - & - \\
\hline GIRLCLOS & - & - & $\begin{array}{l}-0.298 \\
(0.239)\end{array}$ & 1.347 & - & - \\
\hline COEDCLOS & - & - & $\begin{array}{c}0.081 \\
(0.170)\end{array}$ & 0.922 & - & - \\
\hline PRIMYES & - & - & - & - & $\begin{array}{l}-0.035 \\
(0.136)\end{array}$ & 0.966 \\
\hline
\end{tabular}

Note: $\quad{ }^{\mathrm{a}}$ The normalised category is: both school and work.

${ }^{\mathrm{b}}$ (Heteroskedasticity consistent) standard errors in brackets.

${ }^{\mathrm{c}}$ Denotes significance at $5 \%$ significance level. 
Table 6: Multinomial Logit Estimates for Category ${ }^{\mathrm{a}}$ : Neither in School nor in Work

\begin{tabular}{|c|c|c|c|c|c|c|}
\hline \multirow{2}{*}{ Variable } & \multicolumn{2}{|c|}{ Peru } & \multicolumn{2}{|c|}{ Pakistan } & \multicolumn{2}{|c|}{ Ghana } \\
\hline & $\begin{array}{l}\text { Coefficient } \\
\text { Estimate }^{b}\end{array}$ & $\begin{array}{c}\text { Relative } \\
\text { Risk Ratio }\end{array}$ & $\begin{array}{l}\text { Coefficient } \\
\text { Estimate }^{b}\end{array}$ & $\begin{array}{c}\text { Relative } \\
\text { Risk Ratio }\end{array}$ & $\begin{array}{l}\text { Coefficient } \\
\text { Estimate }^{b}\end{array}$ & $\begin{array}{c}\text { Relative } \\
\text { Risk Ratio }\end{array}$ \\
\hline AGE & $\begin{array}{l}-1.745^{\mathrm{c}} \\
(0.143)\end{array}$ & 0.175 & $\begin{array}{l}-1.232^{c} \\
(0.374)\end{array}$ & 0.292 & $\begin{array}{c}-1.891^{\mathrm{c}} \\
(.136)\end{array}$ & 0.151 \\
\hline AGE2 & $\begin{array}{l}0.072^{c} \\
(0.006)\end{array}$ & 1.075 & $\begin{array}{l}0.047^{\mathrm{c}} \\
(0.014)\end{array}$ & 1.048 & $\begin{array}{c}0.072^{c} \\
(0.006)\end{array}$ & 1.074 \\
\hline GIRL & $\begin{array}{l}1.106^{\mathrm{c}} \\
(0.030)\end{array}$ & 3.023 & $\begin{array}{l}2.566^{\mathrm{c}} \\
(0.142)\end{array}$ & 13.012 & $\begin{array}{l}0.918^{\mathrm{c}} \\
(0.109)\end{array}$ & 2.505 \\
\hline URBAN & $\begin{array}{l}1.344^{\mathrm{c}} \\
(0.198)\end{array}$ & 3.835 & $\begin{array}{c}0.290 \\
(0.302)\end{array}$ & 1.337 & $\begin{array}{l}-0.009 \\
(0.159)\end{array}$ & 0.992 \\
\hline NCHILD & $\begin{array}{c}0.020 \\
(0.040)\end{array}$ & 1.020 & $\begin{array}{c}0.012 \\
(0.022)\end{array}$ & 1.012 & $\begin{array}{l}-0.038 \\
(0.023)\end{array}$ & 0.963 \\
\hline NADULT & $\begin{array}{l}0.151^{\mathrm{c}} \\
(0.051)\end{array}$ & 1.163 & $\begin{array}{c}0.020 \\
(0.032)\end{array}$ & 1.020 & $\begin{array}{l}0.136^{\mathrm{c}} \\
(0.044)\end{array}$ & 1.146 \\
\hline AMOUNTL & - & - & $\begin{array}{l}-0.000^{\mathrm{c}} \\
(0.000)\end{array}$ & 1.000 & $\begin{array}{l}-0.000 \\
(0.000)\end{array}$ & 1.000 \\
\hline AMOUNTB & - & - & $\begin{array}{l}-0.000^{c} \\
(0.000)\end{array}$ & 1.000 & $\begin{array}{l}0.000^{c} \\
(0.000)\end{array}$ & 1.000 \\
\hline FHH & $\begin{array}{l}-0.051 \\
(0.246)\end{array}$ & 0.950 & $\begin{array}{l}-0.257 \\
(0.412)\end{array}$ & 0.774 & $\begin{array}{c}0.193 \\
(0.126)\end{array}$ & 1.213 \\
\hline HEADAGE & $\begin{array}{l}0.014^{\mathrm{c}} \\
(0.007)\end{array}$ & 1.014 & $\begin{array}{c}0.005 \\
(0.005)\end{array}$ & 1.005 & $\begin{array}{l}-0.008 \\
(0.004)\end{array}$ & 0.992 \\
\hline LANGHH & - & - & $\begin{array}{l}-0.353 \\
(0.182)\end{array}$ & 0.702 & $\begin{array}{l}-0.448^{c} \\
(0.135)\end{array}$ & 0.639 \\
\hline MAXFEMED & $\begin{array}{l}0.025^{\mathrm{c}} \\
(0.017)\end{array}$ & 1.026 & $\begin{array}{c}0.027 \\
(0.020)\end{array}$ & 0.973 & $\begin{array}{l}-0.177^{\mathrm{c}} \\
(0.014)\end{array}$ & 0.838 \\
\hline MAXMWAGE & $\begin{array}{c}0.033 \\
(0.030)\end{array}$ & 1.034 & $\begin{array}{l}-0.012^{c} \\
(0.004)\end{array}$ & 0.988 & $\begin{array}{l}-0.000^{c} \\
(0.000)\end{array}$ & 1.000 \\
\hline MAXFWAGE & $\begin{array}{l}-0.022 \\
(0.050)\end{array}$ & 1.023 & $\begin{array}{l}-0.102^{c} \\
(0.017)\end{array}$ & 0.903 & $\begin{array}{l}0.000^{\mathrm{c}} \\
(0.000)\end{array}$ & 1.000 \\
\hline MAXFWAGE2 & $\begin{array}{l}-0.001 \\
(0.002)\end{array}$ & 0.999 & $\begin{array}{l}0.002^{c} \\
(0.000)\end{array}$ & 1.002 & $\begin{array}{c}0.000 \\
(0.000)\end{array}$ & 1.000 \\
\hline POV & $\begin{array}{l}0.461^{\mathrm{c}} \\
(0.170)\end{array}$ & 1.586 & $\begin{array}{c}0.818^{\mathrm{c}} \\
(0.229)\end{array}$ & 2.267 & $\begin{array}{c}0.038 \\
(0.187)\end{array}$ & 1.038 \\
\hline PCEX & $\begin{array}{l}0.000^{\mathrm{c}} \\
(0.000)\end{array}$ & 1.000 & $\begin{array}{c}0.000 \\
(0.000)\end{array}$ & 1.000 & $\begin{array}{c}0.000 \\
(0.000)\end{array}$ & 1.000 \\
\hline WATER1 & - & - & $\begin{array}{c}0.218 \\
(0.150)\end{array}$ & 1.243 & - & - \\
\hline ROAD & - & - & $\begin{array}{c}0.056 \\
(0.135)\end{array}$ & 1.057 & - & - \\
\hline CLOSEDDR & - & - & $\begin{array}{l}-0.184 \\
(0.199)\end{array}$ & 0.832 & - & - \\
\hline DISPOS1 & - & - & $\begin{array}{c}0.125 \\
(0.191)\end{array}$ & 1.133 & - & - \\
\hline
\end{tabular}


Table 6 (Continued)

\begin{tabular}{|c|c|c|c|c|c|c|}
\hline \multirow[b]{2}{*}{ Variable } & \multicolumn{2}{|c|}{ Peru } & \multicolumn{2}{|c|}{ Pakistan } & \multicolumn{2}{|c|}{ Ghana } \\
\hline & $\begin{array}{l}\text { Coefficient } \\
\text { Estimate }^{b}\end{array}$ & $\begin{array}{c}\text { Relative } \\
\text { Risk Ratio }\end{array}$ & $\begin{array}{l}\text { Coefficient } \\
\text { Estimate }^{b}\end{array}$ & $\begin{array}{c}\text { Relative } \\
\text { Risk Ratio }\end{array}$ & $\begin{array}{l}\text { Coefficient } \\
\text { Estimate }^{b}\end{array}$ & $\begin{array}{c}\text { Relative } \\
\text { Risk Ratio }\end{array}$ \\
\hline DWATER & - & - & - & - & $\begin{array}{l}-0.668^{\mathrm{c}} \\
(0.120)\end{array}$ & 0.513 \\
\hline TOILET & - & - & - & - & $\begin{array}{l}-0.768^{c} \\
(0.119)\end{array}$ & 0.464 \\
\hline LIGHT & - & - & - & - & $\begin{array}{l}-0.150 \\
(0.171)\end{array}$ & 0.861 \\
\hline ELECTR & $\begin{array}{c}0.008 \\
(0.191)\end{array}$ & 1.008 & - & - & - & - \\
\hline WATER2 & $\begin{array}{l}-0.563^{c} \\
(0.174)\end{array}$ & 0.569 & - & - & - & - \\
\hline WATERC & $\begin{array}{c}0.138 \\
(0.130)\end{array}$ & 1.148 & - & - & - & - \\
\hline DISPOS2 & $\begin{array}{c}0.116 \\
(0.214)\end{array}$ & 1.123 & - & - & - & - \\
\hline BOYSC & - & - & $\begin{array}{l}-0.012 \\
(0.035)\end{array}$ & 0.988 & - & - \\
\hline GIRLSC & - & - & $\begin{array}{l}-0.306^{c} \\
(0.065)\end{array}$ & 0.736 & - & - \\
\hline COEDSC & - & - & $\begin{array}{l}-0.057 \\
(0.053)\end{array}$ & 0.945 & - & - \\
\hline BOYCLOS & - & - & $\begin{array}{l}-0.260 \\
(0.273)\end{array}$ & 1.297 & - & - \\
\hline GIRLCLOS & - & - & $\begin{array}{l}-0.543^{c} \\
(0.245)\end{array}$ & 1.721 & - & - \\
\hline COEDCLOS & - & - & $\begin{array}{c}0.050 \\
(0.182)\end{array}$ & 0.951 & - & - \\
\hline PRIMYES & - & - & - & - & $\begin{array}{l}-0.364^{\mathrm{c}} \\
(0.121)\end{array}$ & 0.695 \\
\hline
\end{tabular}

Note: $\quad{ }^{\mathrm{a}}$ The normalised category is: both school and work.

$\mathrm{b}$ (Heteroskedasticity consistent) standard errors in brackets.

${ }^{\mathrm{c}}$ Denotes significance at $5 \%$ significance level. 
Table 7: Multinomial Logit Marginal Probabilities for a Selection of Variables

\begin{tabular}{|c|c|c|c|c|c|c|c|c|c|c|c|c|}
\hline \multirow[b]{2}{*}{ Variable } & \multicolumn{4}{|c|}{ Peru } & \multicolumn{4}{|c|}{ Pakistan } & \multicolumn{4}{|c|}{ Ghana } \\
\hline & $\begin{array}{c}\text { School } \\
\text { Only }\end{array}$ & $\begin{array}{c}\text { Both } \\
\text { School \& } \\
\text { Work }\end{array}$ & $\begin{array}{c}\text { Neither } \\
\text { School } \\
\text { Nor } \\
\text { Work }\end{array}$ & $\begin{array}{l}\text { Work } \\
\text { Only }\end{array}$ & $\begin{array}{c}\text { School } \\
\text { Only }\end{array}$ & $\begin{array}{c}\text { Both } \\
\text { School \& } \\
\text { Work }\end{array}$ & $\begin{array}{c}\text { Neither } \\
\text { School } \\
\text { Nor } \\
\text { Work }\end{array}$ & $\begin{array}{l}\text { Work } \\
\text { Only }\end{array}$ & $\begin{array}{c}\text { School } \\
\text { Only }\end{array}$ & $\begin{array}{c}\text { Both } \\
\text { School \& } \\
\text { Work }\end{array}$ & $\begin{array}{c}\text { Neither } \\
\text { School } \\
\text { Nor } \\
\text { Work }\end{array}$ & $\begin{array}{l}\text { Work } \\
\text { Only }\end{array}$ \\
\hline AGE & 0.0212 & 0.0735 & -0.0887 & -0.0060 & 0.0275 & 0.0412 & -0.1173 & 0.0486 & 0.0518 & 0.1137 & -0.2168 & 0.0513 \\
\hline GIRL & 0.0797 & -0.1029 & 0.0321 & -0.0089 & -0.2363 & -0.0754 & 0.2858 & 0.0259 & -0.1159 & -0.0449 & 0.1344 & 0.0264 \\
\hline URBAN & 0.2733 & -0.2587 & -0.0028 & -0.0118 & 0.2029 & -0.0412 & -0.1055 & -0.0562 & 0.0493 & -0.0026 & -0.0102 & -0.0364 \\
\hline NCHILD & -0.0100 & 0.0060 & 0.0040 & 0.0000 & -0.0061 & 0.0002 & 0.0035 & 0.0024 & -0.0033 & 0.0037 & -0.0003 & -0.0001 \\
\hline NADULT & 0.0105 & -0.0148 & 0.0041 & 0.0002 & 0.0246 & -0.0019 & -0.0036 & -0.0190 & -0.0178 & -0.0065 & 0.0206 & 0.0037 \\
\hline FHH & -0.0007 & -0.0050 & -0.0055 & 0.0112 & -0.0468 & 0.0207 & 0.0154 & 0.0107 & 0.0652 & -0.0206 & -0.0071 & -0.0375 \\
\hline HEADAGE & -0.0010 & -0.0001 & 0.0009 & 0.0002 & -0.0012 & -0.0001 & 0.0007 & 0.0006 & -0.0002 & 0.0006 & -0.0006 & 0.0001 \\
\hline MAXFEMED & 0.0064 & -0.0045 & -0.0002 & -0.0017 & 0.0283 & -0.0009 & -0.0104 & -0.0169 & 0.0373 & 0.0062 & -0.0333 & -0.0103 \\
\hline POV & -0.0385 & -0.0006 & 0.0364 & 0.0027 & -0.1144 & -0.0225 & 0.0890 & 0.0479 & -0.1494 & 0.0224 & 0.0790 & 0.0481 \\
\hline
\end{tabular}


Table 8: Ordered $^{\mathrm{a}}$ Probit Estimates $^{\mathrm{b}}$ by Country

\begin{tabular}{|c|c|c|c|}
\hline Variable & Peru & Pakistan & Ghana \\
\hline AGE & $-0.268^{c}$ & 0.017 & $-0.196^{\circ}$ \\
\hline & $(0.042)$ & $(0.093)$ & $(0.037)$ \\
\hline AGE2 & $0.018^{c}$ & 0.005 & $0.013^{c}$ \\
\hline & $(0.002)$ & $(0.003)$ & $(0.002)$ \\
\hline GIRL & $-0.117^{\mathrm{c}}$ & $0.426^{c}$ & $0.268^{\mathrm{c}}$ \\
\hline & $(0.036)$ & $(0.032)$ & $(0.033)$ \\
\hline URBAN & $-0.582^{c}$ & $-0.240^{c}$ & $-0.167^{\circ}$ \\
\hline & $(0.059)$ & $(0.079)$ & $(0.050)$ \\
\hline NCHILD & $0.024^{c}$ & $0.014^{\mathrm{c}}$ & 0.002 \\
\hline NADULT & $\begin{array}{c}(0.011) \\
0.000\end{array}$ & $\begin{array}{c}(0.006) \\
-0.051^{c}\end{array}$ & $\begin{array}{l}(0.007) \\
0.045^{\mathrm{c}}\end{array}$ \\
\hline PVADE & $(0.016)$ & $(0.009)$ & $(0.013)$ \\
\hline AMOUNTL & & $\begin{array}{c}0.000 \\
(0.000)\end{array}$ & $\begin{array}{c}0.000 \\
(0.000)\end{array}$ \\
\hline AMOUNTB & & $\begin{array}{c}0.000 \\
(0.000)\end{array}$ & $\begin{array}{c}0.000 \\
(0.000)\end{array}$ \\
\hline FHH & 0.062 & 0.083 & $-0.208^{c}$ \\
\hline & $(0.076)$ & $(0.113)$ & $(0.040)$ \\
\hline HEADAGE & $\begin{array}{l}0.004^{\mathrm{c}} \\
(0.002)\end{array}$ & $\begin{array}{c}0.003 \\
(0.001)\end{array}$ & $\begin{array}{c}0.001 \\
(0.001)\end{array}$ \\
\hline LANGHH & & $\begin{array}{l}-0.154^{\mathrm{c}} \\
(0.049)\end{array}$ & $\begin{array}{l}-0.025 \\
(0.045)\end{array}$ \\
\hline MAXFEMED & $-0.022^{c}$ & $-0.066^{c}$ & $-0.090^{\circ}$ \\
\hline MAXMWAGE & $\begin{array}{l}(0.005) \\
-0.009^{c}\end{array}$ & $\begin{array}{l}(0.006) \\
-0.006^{c}\end{array}$ & $\begin{array}{c}(0.004) \\
0.000\end{array}$ \\
\hline & $(0.007)$ & $(0.001)$ & $(0.000)$ \\
\hline MAXFWAGE & 0.006 & $0.024^{c}$ & 0.000 \\
\hline MAXFWAGE2 & $\begin{array}{c}(0.013) \\
0.000\end{array}$ & $\begin{array}{c}(0.005) \\
0.000\end{array}$ & $\begin{array}{c}(0.000) \\
0.000\end{array}$ \\
\hline & $(0.000)$ & $(0.000)$ & $(0.000)$ \\
\hline POV & $0.131^{\mathrm{c}}$ & $0.286^{\mathrm{c}}$ & $0.326^{\mathrm{c}}$ \\
\hline PCEXP & $\begin{array}{c}(0.047) \\
0.000\end{array}$ & $\begin{array}{l}(0.054) \\
0.000^{c}\end{array}$ & $\begin{array}{c}(0.055) \\
0.000\end{array}$ \\
\hline & $(0.000)$ & $(0.000)$ & $(0.000)$ \\
\hline ELECTR1 & $-0.287^{c}$ & & \\
\hline & $(0.055)$ & & \\
\hline WATER1 & 0.015 & & \\
\hline WATERC1 & $\begin{array}{c}(0.047) \\
0.053\end{array}$ & & \\
\hline & $(0.037)$ & & \\
\hline DISPOS1 & $\begin{array}{c}-0.149^{\mathrm{c}} \\
(0.064)\end{array}$ & & \\
\hline
\end{tabular}


Table 8 (Continued)

\begin{tabular}{|c|c|c|c|}
\hline Variable & Peru & Pakistan & Ghana \\
\hline WATER1 & & $\begin{array}{l}-0.193^{c} \\
(0.039)\end{array}$ & \\
\hline ROAD1 & & $-0.131^{c}$ & \\
\hline & & $(0.035)$ & \\
\hline CLOSEDDR & & $-0.170^{c}$ & \\
\hline DISPOS4 & & 0.074 & \\
\hline & & (0.048) & \\
\hline BOYSC & & $\begin{array}{c}0.001 \\
(0.010)\end{array}$ & \\
\hline GIRLSC & & -0.041 & \\
\hline & & $(0.020)$ & \\
\hline COEDSC & & $0.049^{c}$ & \\
\hline & & $\begin{array}{c}(0.015) \\
0.000\end{array}$ & \\
\hline & & $(0.073)$ & \\
\hline GIRLCLOS & & 0.067 & \\
\hline COEDCLOS & & -0.088 & \\
\hline & & $(0.051)$ & \\
\hline DWATERIO & & & $\begin{array}{c}-0.060 \\
(0.038)\end{array}$ \\
\hline LIGHT2 & & & $0.187^{\mathrm{c}}$ \\
\hline PRIMYES & & & $\begin{array}{l}(0.053) \\
-0.057\end{array}$ \\
\hline & & & $(0.038)$ \\
\hline Thresholds & -0.504 & 0.702 & -0.745 \\
\hline & $(0.247)$ & $(0.615)$ & $(0.214)$ \\
\hline$\mu_{2}$ & 0.394 & 0.922 & -0.369 \\
\hline & $(0.250)$ & $(0.615)$ & $(0.214)$ \\
\hline$\mu_{3}$ & 1.010 & 1.742 & 0.682 \\
\hline & $(0.246)$ & $(0.615)$ & $(0.210)$ \\
\hline
\end{tabular}

Notes:

${ }^{\mathrm{a}}$ Categories ordered in terms of child welfare.

${ }^{\mathrm{b}}$ (Heteroskedasticity consistent) Standard errors in brackets.

${ }^{\mathrm{c}}$ Denotes significance at 5\% significant level. 
Table 9: Marginal Results for the Ordered Probit Estimates for Selected Variables

\begin{tabular}{|c|c|c|c|c|c|c|c|c|c|c|c|c|}
\hline & School Only & $\begin{array}{r}\text { Pe } \\
\text { Both School } \\
\text { \& Work }\end{array}$ & $\begin{array}{l}\text { ru } \\
\text { Neither } \\
\text { School Nor } \\
\text { Work }\end{array}$ & Work Only & School Only & $\begin{array}{r}\text { Paki } \\
\text { Both School } \\
\text { \& Work }\end{array}$ & $\begin{array}{l}\text { istan } \\
\text { Neither } \\
\text { School Nor } \\
\text { Work }\end{array}$ & Work Only & School Only & $\begin{array}{l}\text { Gha } \\
\text { Both School } \\
\text { \& Work }\end{array}$ & $\begin{array}{l}\text { ana } \\
\text { Neither } \\
\text { School Nor } \\
\text { Work }\end{array}$ & Work Only \\
\hline AGE & 0.094 & -0.054 & -0.026 & 0.014 & -0.007 & 0.000 & 0.003 & -0.004 & 0.078 & -0.003 & -0.043 & 0.032 \\
\hline GIRL & 0.041 & -0.024 & -0.011 & -0.006 & -0.168 & 0.002 & 0.062 & 0.105 & -0.106 & 0.004 & 0.058 & 0.044 \\
\hline URBAN & 0.206 & -0.113 & -0.059 & -0.034 & 0.095 & -0.001 & -0.035 & -0.059 & 0.066 & -0.004 & -0.038 & -0.025 \\
\hline NCHILD & -0.008 & 0.005 & 0.002 & -0.001 & -0.006 & 0.000 & 0.002 & -0.003 & -0.001 & 0.000 & 0.000 & 0.000 \\
\hline NADULT & 0.000 & 0.000 & 0.000 & 0.000 & 0.020 & 0.000 & -0.008 & 0.012 & -0.018 & 0.001 & 0.010 & -0.007 \\
\hline $\mathrm{FHH}$ & -0.022 & 0.013 & 0.006 & 0.003 & -0.033 & 0.000 & 0.012 & 0.021 & 0.083 & -0.004 & -0.047 & -0.032 \\
\hline MAXFEMED & 0.008 & -0.005 & -0.002 & 0.001 & 0.027 & 0.000 & -0.010 & 0.016 & 0.036 & -0.001 & -0.020 & 0.015 \\
\hline POV & -0.046 & 0.026 & 0.013 & 0.007 & -0.112 & -0.001 & 0.036 & 0.078 & -0.126 & -0.001 & 0.065 & 0.063 \\
\hline PCEXP & 0.000 & 0.000 & 0.000 & 0.000 & 0.000 & 0.000 & 0.000 & 0.000 & 0.000 & 0.000 & 0.000 & 0.000 \\
\hline
\end{tabular}




\section{References:}

Ashagrie, K. (1993), "Statistics on Child Labour", Bulletin of Labour Statistics, Issue No. 3, ILO, Geneva.

Basu, K. (1999), "Child Labour: Cause, Consequence and Cure with Remarks on International Labour Standards", Journal of Economic Literature, 37(3), 1083-1119.

Basu, K. (2000), "The Intriguing Relation Between Adult Minimum Wage and Child Labour", The Economic Journal, 110, C50-C61.

Basu, K. and P.H. Van (1998), "The Economics of Child Labour", American Economic Review, 88(3), 412-427.

Bhalotra, S. (1999), "Is Child Work Necessary?”, Mimeo, Cambridge University.

Bonnet, M. (1993), “Child Labour in Africa”, International Labour Review, 132(3), 371-389.

Canagarajah, S. and Coulombe, H. (1998), "Child Labor and Schooling in Ghana", Mimeographed World Bank, Washington D.C.

Cartwright, K. (1999), "Child Labour in Colombia", Ch. 4 in Grootaert and Patrinos (1999, eds.).

Cigno, A., Rosati, F. and Z. Tzannatos (2000), Child Labor, nutrition and education in rural India: An economic analysis of parental choice and policy options, paper presented at the World Bank Conference on Child Labour, Washington, D.C. (April 11-13, 2000)

Fallon, P. and Z. Tzannatos (1998), Child Labour: Issues and Directions for the World Bank, Human Development Network, The World Bank, Washington DC.

Grootaert, C. (1999), "Child Labour in Cote d Invoire", Ch. 3 in Grootaert and Patrinos (1999, eds.)

Grootaert, C. and R. Kanbur (1995), "Child Labour: An Economic Perspective”, International Labour Review, 134(2), 187-203.

Grootaert, C. and H.A. Patrinos (1999), The Policy Analysis of Child Labour: A Comparative Study, St. Martin's Press, New York.

Grosh, M. and P. Glewwe (1995), A Guide to Living Standards Measurement Surveys and their Data Sets, LSMS Working Paper No. 120, World Bank, Washington, DC.

ILO (1996), Economically Active Populations: Estimates and Projections, 1950-2010, International Labour Organisation, Geneva.

Jafarey, S. and S. Lahiri (2000), "Will Trade Sanctions Reduce Child Labour? The Role of Credit Markets", Mimeo, University of Essex.

Jensen, P. and H. S. Nielsen (1997), "Child Labour or School Attendance? Evidence from Zambia", Journal of Population Economics, 10(4), 407-424.

Nielsen, H. S. (1999), “Child Labor and School Attendance: Two Joint Decisions", Mimeo Aarhus School of Business.

Patrinos, H.A and G. Psacharopoulos (1997), "Family Size, Schooling and Child Labour in Peru: An Empirical Analysis", Journal of Population Economics, 10(4), 387-406.

Psacharopoulos, G. (1997), "Child Labour Versus Educational Attainment: Some Evidence from Latin America”, Journal of Population Economics, 10(4), 377-386. 
Ravallion, M. and Q. Wodon (2000), "Does Child Labour Displace Schooling? Evidence on Behavioural Responses to an Enrolment Subsidy", The Economic Journal, C158C175.

Ray, R. (2000a), "Analysis of Child Labour in Peru and Pakistan: A Comparative Study", Journal of Population Economics.

Ray, R. (2000b), "Child Labour, Child Schooling and their Interaction with Adult Labour", The World Bank Economic Review, 14(2), 347-367.

Rosati, F.C. and Z. Tzannatos (2000), "Child Labor in Vietnam", Mimeo, The World Bank Washington.

Weiner, M. (1996), "Child Labour in India: Putting Compulsory Primary Education on the Political Agenda", Economic and Political Weekly, 31, 45-46. 


\section{End Notes:}

\footnotetext{
${ }^{1}$ See for example Fallon and Tzannatos (1998) who discuss ways in which the World Bank can assist member nations in reducing child labour.

${ }^{2}$ For example in Latin American countries a large number of children combine schooling and labour market participation while in South Asian countries a large number of children do neither.

${ }^{3}$ See also the volume edited by Grootaert and Patrinos (1999).

${ }^{4}$ There are studies, which examine other aspects of child labour market participation. Ray (2000b) examines the hours of work and the interaction between child wages and adult wages. Bhalotra (2000) uses hours of work to examine whether child labour is "necessary".

${ }^{5}$ See Grosh and Glewwe (1995) for an overview and general description of the LSMS data sets.

${ }^{6}$ In particular this ignores the huge number of children that work at home helping the adults in domestic activity (for example cooking, cleaning or taking care of children) or providing an additional hand in own farm activities.

${ }^{7}$ We only consider the child earnings from formal wage labour and ignore, for lack of data, the child's contribution to domestic work or to work in family farms.

${ }^{8}$ The poverty line was set at $50 \%$ of the median sample per adult equivalent non-child household income.
} 